\section{Riboflavine and Thiamine Contents of Saffron, Crocus sativus Linn.}

Four authenticated samples of saffron were analysed by us for the presence of riboflavine and thiamine by use of the spectrophotometer. An acetic acid buffer $(p \mathrm{H} 4 \cdot 5)$ extract of saffron to which papain was added was taken. The pigment in the extract obtained (after destroying the enzyme papain by heating) was destroyed by addition of $10 \mathrm{ml}$. of 4 per cent potassium permanganate after adjusting the extract to $p \mathrm{H} 3 \cdot 7$ with glacial acetic acid. Hydrogen peroxide was added to destroy the excess of permanganate. The filtrate obtained was made up to volume and its fluorescence read on a spectrophotometer. The presence of fluorescing substances other than riboflavine was ruled out because on addition of sodium hydrosulphite solution in $0.2 M$ disodium phosphate, no fluorescence was observed, which would not have been the case had fluorescent substances other than riboflavine been present in the extract ${ }^{1}$. By treating an aliquot of the permanganate extract obtained above with alkaline potassium ferrocyanide and isobutyl alcohol, the thiamine was oxidized to thiochrome $^{2}$ which gets transferred to the isobutyl alcohol layer because of its greater solubility in that solvent. After drying this extract over anhydrous sodium sulphate, readings for thiamine were taken on the spectrophotometer.

The results of the analysis are presented in the accompanying table. Along with the results obtained for saffron, the riboflavine contents of other foods considered to be rich sources of this vitamin, and also some plant parts classed as spices, have been presented.

\begin{tabular}{|c|c|c|c|c|}
\hline Product or plant & Plant part & $\begin{array}{l}\text { Thi- } \\
\text { amine } \\
y / g m .\end{array}$ & $\begin{array}{c}\text { Ribo- } \\
\text { flavine } \\
\text { v/gm. }\end{array}$ & Authors \\
\hline $\begin{array}{cc}\text { Saffron: } & \\
\text { Sample } & \text { I } \\
\text { ": } & \text { III } \\
", & \text { IV } \\
\end{array}$ & & $\begin{array}{l}4 \cdot 0 \\
3 \cdot 8 \\
0 \cdot 72 \\
0 \cdot 88 \\
\end{array}$ & $\begin{array}{r}138 \\
93 \cdot 3 \\
78 \cdot 7 \\
56 \cdot 4 \\
\end{array}$ & \\
\hline $\begin{array}{l}\text { Beta vulgaris } \\
\text { Spinacea oleracea } \\
\text { Cucurbita } \\
\text { mexicand } \\
\text { Avena sativa }\end{array}$ & $\begin{array}{l}\text { Leaves } \\
\text { Leaves } \\
\text { Dry } \\
\text { flowers } \\
\text { Coleoptile } \\
\text { of embryo }\end{array}$ & & $\begin{array}{l}20 \\
22 \\
25 \\
20\end{array}$ & $\begin{array}{l}\text { Cheldelin and } \\
\text { Williams, } 1942 \\
\text { Cheldelin and } \\
\text { Williams, 1942 } \\
\text { Cravioto et al., } \\
1945 \\
\text { Cravioto et al., } \\
1945\end{array}$ \\
\hline $\begin{array}{l}\text { Ferula narthex } \\
\text { Allium sativum } \\
\text { Myristica } \\
\text { fragrans }\end{array}$ & $\begin{array}{l}\text { Gum resin } \\
\text { from root } \\
\text { Bulb } \\
\text { Rind }\end{array}$ & & & $\begin{array}{ll}\text { Aykroyd, } & 1951 \\
\text { Aykroyd, } & 1951 \\
\text { Aykroyd, } & 1951\end{array}$ \\
\hline $\begin{array}{l}\text { Marmite } \\
\text { Dry egg albumin } \\
\text { Dried yeast } \\
\text { Dried whey } \\
\text { Fresh ox liver } \\
\text { Calf liver } \\
\text { Pork liver }\end{array}$ & & & $\begin{array}{l}33 \\
14 \cdot 1 \\
30-50 \\
20 \\
15 \cdot 9 \\
32 \\
27\end{array}$ & $\begin{array}{l}\text { Morton, 1942 } \\
\text { Morton, } 1942 \\
\text { Morton, 1942 } \\
\text { Morton, 1942 } \\
\text { Morton, 1942 } \\
\text { Elvehjem, 1943 } \\
\text { Elvehjem, 1943 }\end{array}$ \\
\hline
\end{tabular}

It will be noticed that saffron or the stigmas of Crocus sativus Linn, are easily the richest known source of vitamin $B_{2}$ or riboflavine. The thiamine or vitamin $B_{1}$ content is, however, insignificant.

High values for riboflavine contents of two of the saffron samples chemically analysed by us have also been secured by Dr. K. K. Iya and Mr. Sreenivasamurthy of the Indian Dairy Research Institute, Bangalore, who carried out the microbiological assay using $L$. plantarum-89 as the test organism. 'The authors are grateful to them for their kind co-operation.

Pathological Laboratories,

J. V. BHAT

St. Xavier's College,

Bombay. May 4.

1 Scott, M. L., Hill, F. W., Norris, L. C., and Heuser, G. F., J. Biol. Chem., 165,65 (1946).

2 The Association of Vitamin Chemists, Inc., "Methods of Vitamin Assay", 107 (Interscience Publishers, Inc., New York, 2nd edit., 1951).

\section{Fibrinolysis by Adsorption}

THE plasma of normal people has been shown to contain a labile, active fibrinolysin ${ }^{1,2,3}$. Since this enzyme is not necessarily plasmin and in some ways behaves differently from plasmin, it has been tentatively termed 'plasma active fibrinolysin'2. The enzyme disappears rapidly from fluid blood and plasma kept at room temperature; but if blood is cooled immediately when taken and centrifuged at low temperature and the resultant plasma is diluted and clotted, lysis of the clots occurs within $24 \mathrm{hr}$. incubation at $37^{\circ} \mathrm{C} .^{2}$. Enzyme activity is insufficient to cause anything but slow and variable lysis of whole plasma clots ${ }^{4}$. Since lysis occurs on incubation, the enzyme is evidently stabilized once clotting has taken place, presumably by adsorption on fibrin. This suggested that pre-formed plasma clots might absorb the enzyme from fresh plasma. To investigate this possibility fifteen healthy individuals were studied. Citrated venous blood was obtained from each, and the resultant plasma kept at room temperature for 24 hours in order that all fibrinolytic activity should have disappeared. From this plasma, diluted $1: 4$ with a veronal saline buffer $(p H \mathrm{H} \cdot 4), 1 \cdot 0-\mathrm{ml}$. volume clots were made in small tubes by recalcification. The clots were ringed, removed from the tubes, and kept in normal saline for $2 \mathrm{hr}$.; clots made in this way do not retract appreciably, nor do they cause coagulation of added plasma. The subject was bled again, the blood being citrated and cooled immediately and then centrifuged at low temperature. Three of the clots described above were then placed in $3.0 \mathrm{ml}$. vol. of this plasma (fresh plasma) in tubes standing in ice and water. Adsorption was allowed to continue for $1 \mathrm{hr}$., the tubes being tilted every $2 \frac{1}{2} \mathrm{~min}$. to ensure change of contact between clot and plasma. The clots were then washed thoroughly in saline. After the remainder of the plasma of the second bleeding had stood at room temperature for $4 \mathrm{hr}$., and had lost fibrinolytic activity, the above procedure was repeated exactly using this plasma (standing plasma) and three further clots. Control clots were placed in saline at $0^{\circ} \mathrm{C}$. for $1 \mathrm{hr}$. The clots were then incubated in veronal saline buffer at $37^{\circ} \mathrm{C}$. for $48 \mathrm{hr}$., and examined at intervals for lysis. Whereas no lysis of the clots treated with 'standing' plasma or of the controls occurred, on every occasion the clots treated with 'fresh' plasma underwent lysis of varying degree.

Further experiments showed that whole plasma clots made from silicone-taken blood (that is, no anticoagulant and no clotting agent were added) underwent considerable lysis on incubation after treatment with 'fresh' plasma but not after treatment with 4-hr. 'standing' plasma. Exercise of the subject before venepuncture increased the fibrinolytic effect of the plasma in which the clots were suspended. These data indicate that 'plasma active fibrinolysin' is present in undiluted plasma, from which it can 